\title{
Pendekatan Penginjilan Kontekstual Paulus Berdasarkan Kisah Para Rasul 17:16-34
}

\section{Paul's Contextual Evangelistic Approach Based on Acts 17: 16-34}

\author{
Sugiono ${ }^{1 *}$ \\ 1) Sekolah Tinggi Teologi Kanaan Nusantara \\ *Penulis Korespondensi: panjhisugiono85@gmail.com
}

Received: 1506 2020/ Accepted: 0612 2020/ Published: 07122020

\begin{abstract}
Abstrak
Istilah kontekstual selalu dipakai dalam dunia teologi penginjilan dan misi. Istilah ini menunjuk kepada suatu pola pendekatan penginjilan atau misi yang bisa diterima oleh konteks di mana aksi penginjilan atau misi dilakukan. Kontekstualisasi merupakan langkah atau upaya yang tepat untuk membahasakan berita Injil ke dalam masyarakat yang majemuk sekarang ini. Penulis dalam penulisan jurnal ilmiah ini akan mengadakan penelitian tentang pelayanan penginjilan kontekstual yang Paulus gunakan di Atena berdasarkan Kisah Para Rasul 17:16-34, untuk dijadikan sebuah model penginjilan kontekstual yang relevan pada masa sekarang ini. Bentuk pendekatan yang digunakan adalah kualitatif dengan pendekatan eksegesis di mana teknik pengumpulan data adalah melakukan penafsiran terhadap teks dengan bantuan kajian ilmu hermeneutik dan pustaka. Berdasarkan hasil analisis terhadap pendekatan penginjilan kontekstual Paulus berdasarkan Kisah Para Rasul 17:16:34, maka dapat ditarik sebuah hasil sebagai contoh model penginjilan kontekstual masa kini. Hasil dan pembahasan yang diperoleh: model dialog interaktif persuasif (ay. 17-18), model identifikasi religiokultural (ay. 22-23), model akomodasi lokatif (ay. 19,22), model adopsi literalis (ay. 2324).
\end{abstract}

Kata-kata Kunci: Kontekstual, Model dan Masa Kini, Paulus, Pendekatan, Penginjilan.

\begin{abstract}
The term contextual is always used in the world of evangelical theology and mission. This term refers to a pattern of evangelistic or mission approach that is acceptable to the context in which the evangelistic or missionary action is carried out. Contextualization is the right step or effort to bring the message of the gospel into today's pluralistic society. This scientific journal will research the contextual evangelistic ministry that Paul used in Athens based on Acts 17:16-34, to be used as a model of contextual evangelism that is relevant today. The form of the approach used is qualitative research with exegesis approach in which the data collection technique is to
\end{abstract}


interpret the text with the help of hermeneutic studies and literature. Based on the analysis of Paul's contextual evangelistic approach based on Acts 17:16:34, an outcome can be drawn as an example of the present contextual evangelistic model. Results and discussion obtained: a persuasive interactive dialogue model (17-18), a religion-cultural identification model (22-23), a locative accreditation model $(19,22)$, a literal adoption model (23-24).

Keywords: Approach, Contextual, Evangelism, Model and Present, Paul.

\section{PENDAHULUAN}

Pemberitaan Injil adalah salah satu dari fungsi gereja (Ellis, 1997, p. 7). Hal tersebut menegaskan bahwa Memberitakan Injil adalah tanggung jawab setiap orang Kristen. Karena berita Injil merupakan suatu jawaban dari kebutuhan manusia (Roma 1:16) maka Injil Markus 16:15, mengatakan: "... Pergilah ke seluruh dunia, beritakan Injil kepada segala makhluk." Makna ungkapan tersebut menjelaskan dengan tegas, bahwa amanat agung Tuhan Yesus bersifat mutlak dan harus dilaksanakan. Hasselgrave mengungkapkan bahwa urgensi pelaksanaan penginjilan perlu mendapat perhatian orang Kristen karena "Allah menghendaki semua orang Kristen memberitakan Injil (penginjilan), supaya dunia mendengarkan kabar tentang Injil (Hasselgrave, 2004, p. 13).

Hal serupa juga disebutkan oleh Purnawan bahwa misi gereja tidak bisa dipisahkan dari Amanat Agung Tuhan Yesus (Purnawan, 2019, p. 23-36). Oleh berbagai aliran dan denominasi gereja, Amanat Agung tersebut berkaitan dengan tanggung jawab untuk bermisi, termasuk di dalamnya dipahami sebagai misi pemenangan jiwa. Kewajiban mengabarkan Injil adalah tanggung jawab setiap orang yang telah menerima Kristus menjadi Tuhan dan Juruselamatnya. Orang Kristen perlu melakukan penginjilan supaya Injil dapat didengar dan diterima oleh semua orang dalam konteks budaya. Jenson dalam tulisannya menjelaskan bahwa pada dasarnya Injil tetap menjadi berita yang relevan di sepanjang zaman, budaya, agama, bahasa, dan tradisi di dunia ini (Jenson, 2002, p. 246-247). Tetapi dalam kenyataannya Injil sering menjadi berita yang sulit diterima oleh pendengar, karena seorang penginjil tidak dapat menyampaikan Injil melewati batas-batas pengertian manusia dalam konteks budaya.

Panggara menjelaskan bahwa penting untuk dipahami juga bahwa setiap orang yang terlibat dalam kegiatan misi seharusnya memperhatikan kearifan lokal budaya setempat sehingga dalam pengomunikasian Injil dapat diterima dengan lebih baik (Panggara, 2019, p. 91). Maka tidaklah mengherankan bila dalam kebudayaan tertentu, berita Injil dianggap asing dalam kehidupan mereka. Hal ini disebabkan oleh 
adanya nilai-nilai budaya, agama, bahasa, dan tradisi yang pada umumnya memengaruhi perilaku seseorang dalam konteksnya. Karena itu seorang penginjil perlu memperhatikan hal tersebut supaya berita Injil menjadi relevan dalam kehidupan masyarakat yang majemuk.

Hal serupa juga dinyatakan Susanto bahwa kegiatan misi untuk memenuhi Amanat Agung merupakan bagian penting yang tidak bisa dipisahkan dari kehidupan orang percaya maupun gereja Tuhan (Susanto, 2019, p. 56-73). Tugas memberitakan Injil merupakan tanggung jawab setiap orang yang percaya kepada Yesus Kristus, namun ada sebagian orang Kristen di beberapa tempat merasa enggan untuk memberitakan Injil. Matakupan menjelaskan bahwa ada yang beranggapan bahwa tugas penginjil hanyalah bagi orang-orang yang hidupnya sepenuh waktu bagi Tuhan seperti pendeta, penginjil, majelis dan lainnya (Matakupan, 2002, p. 7). Ada juga orang Kristen yang merasa takut dan tidak tahu bagaimana cara menyampaikan Injil. Suhendro mengungkapkan bahwa penginjilan sebagai gaya hidup orang percaya. Gaya hidup seperti itu merupakan harga mati bagi orang percaya sebab itulah yang dikehendaki oleh Bapa di sorga. Sebagai orang yang sudah merdeka dari perilaku dunia maka sebaiknya kita menunjukkan jati diri kita sebagai orang yang percaya (Suhendro, 2018, p. 16).

Latar belakang itulah yang menyebabkan beberapa orang Kristen beranggapan bahwa memberitakan Injil merupakan tugas yang berat untuk dilakukan. Untuk mengatasi permasalahan tersebut seharusnya gereja mulai bergerak dan memperlengkapi jemaat dengan pemahaman yang benar, sehingga jemaat mempunyai keberanian untuk melaksanakan tanggung jawab mengabarkan Injil dengan baik. Hesselgrave dalam bukunya Planting Churches Cross-Culture a Guide for Home and Foreign Missions mengatakan The most important center of Christian educations is the local church itself. But the larger implications of New testament evangelism and the heart of mission need to be understood by all. Evangelism should lead converts to active participation in the local church; whatever else world mission may entail, it must give first priority to that kind of evangelism. This requires understanding and understanding requires careful, prayerful study (Hesselgrave, 1997, p. 66-69). Inti misi perlu diketahui semua orang dan setiap jemaat local perlu terlibat dalam penginjilan.

Di dalam Alkitab sangat jelas sekali dipaparkan bahwa sasaran penginjilan ialah kepada semua orang dalam konteks yang umumnya dipengaruhi oleh budaya, agama, bahasa, dan tradisi yang berbeda (Mat. 28:19-20). Dari kondisi dan latar belakang seperti itulah maka kontekstualisasi merupakan langkah atau upaya yang tepat untuk membahasakan berita Injil ke dalam masyarakat yang majemuk sekarang ini. Manurung menyimpulkan bahwa isi penginjilan tersebut tetaplah berupa penyampaian Injil kepada orang-orang yang belum percaya Kristus melalui sarana keterlibatan aktif gereja dalam aktivitas sosial dan budaya masyarakat setempat (Manurung, 2020, p. 232). Berdasarkan uraian di atas maka dapat ditekankan bahwa setiap penginjil harus benar-benar dipersiapkan dan dibekali dengan pemahaman- 
pemahaman yang tepat dan benar mengenai Injil agar berita yang disampaikannya pun adalah berita yang benar dan tepat tentang Kristus.

Paulus merupakan salah seorang tokoh dalam Alkitab yang menjadi teladan, yang dapat dikatakan berhasil dalam memberitakan Injil dalam kalangan masyarakat majemuk pada zamannya. Paulus berani mempertaruhkan hidupnya untuk kemajuan Injil (Flp. 1:21). Situasi dan kondisi masyarakat pada zamannya tidak memengaruhi atau membatasi Paulus dalam memberitakan Injil. Bahkan melalui situasi dan kondisi yang beranekaragampun dapat dijadikan sebagai sarana untuk memberitakan Injil. Paulus dalam menyampaikan berita Injil selalu menggunakan suatu metode atau prinsip tertentu supaya dirinya dapat diterima oleh pihak manapun. Strategi penginjilan yang digunakan Paulus di kota yang satu berbeda dengan kota-kota atau daerah yang lainnya. Hal tersebut membuktikan bahwa Paulus mampu mempergunakan kondisi dan situasi yang ada sebagai sarana dalam pemberitaan Injil yang efektif. Prinsip yang Paulus terapkan tersebut merupakan suatu langkah yang tepat agar berita Injil dapat dipahami dan diterima oleh semua kalangan masyarakat.

Penulis dalam penulisan jurnal ilmiah ini akan mengadakan penelitian tentang pelayanan penginjilan kontekstual yang Paulus gunakan di Atena berdasarkan Kisah Para Rasul 17:16-34, untuk dijadikan sebuah model penginjilan kontekstual yang relevan pada masa sekarang ini.

\section{TEORI}

\section{Definisi Penginjilan Kontekstual}

Istilah kontekstual selalu dipakai dalam dunia teologi penginjilan dan misi. Istilah ini menunjuk kepada suatu pola pendekatan penginjilan atau misi yang bisa diterima oleh konteks di mana aksi penginjilan atau misi dilakukan. Berdasarkan landasan pemahaman itulah, maka munculah istilah penginjilan yang kontekstual. Menurut Hessegrave istilah "Kontekstualisasi" baru ditambahkan pada bidang misi dan teologi oleh Theological Education Fund (TEF) pada tahun 1972 (Hesselgrave, 2004 , p. 48). Namun, para Misionaris menyadari bahwa ide kontekstualisasi sudah ada jauh sebelumnya yaitu terdapat di dalam Alkitab.

Sedangkan menurut Yakob Tomatala mendefinisikan kata "Kontekstualisasi" sebagai berikut; kata "Kontekstualisasi" (Contextualisation) berasal dari kata 'konteks' (Context) yang diangkat dari kata Latin "Contextere" yang berarti menenun atau menghubungkan bersama (menjadikan satu). Kata benda "Contextus" menunjuk kepada apa yang telah ditenun (tertenun), di mana semuanya telah dihubunghubungkan secara keseluruhan menjadi satu (Tomatala, 1988, p. 21-22).

Beberapa pengertian di atas menjelaskan bahwa berbicara tentang kontekstualisasi perhatian ditujukan kepada dua atau lebih komponen yang disatukan atau dengan kata lain "Kontekstualisasi" berbicara tentang penyatuan beberapa komponen. Untuk memahami istilah ini perlu memahami juga dua istilah yang saling berhubungan yaitu teks dan konteks. David J. Hesselgrave dalam bukunya 
Communicating Christ Cross Culturally mengatakan kontekstualisasi adalah konsep usaha memahami konteks kehidupan manusia secara luas dalam dimensi budaya, agama, sosial, ekonomi, dan politik dalam hubungannya dengan situasi menyeluruh dengan tujuan agar pemberitaan Injil dapat dilakukan dengan baik dan dipahami secara tepat oleh setiap orang yang hidup dalam konteks tersebut (Hesselgrave, 2004, p. 48).

J. I. Packer dalam bukunya yang berjudul Evangelism And The Sovereignty Of God menjelaskan bahwa Kontekstualisasi berarti bahwa kita harus memberikan perhatian serius tidak hanya pada situasi kehidupan dari para penulis Alkitab dan para pembaca asalnya tetapi juga pada situasi iman dan kehidupan dari gereja yang ada di dunia saat ini. Penafsir Alkitab membutuhkan "isi dari konteks itu dan juga konteks ini" untuk menerjemahkan teks agar mempunyai makna yang sangat berarti bagi waktu sekarang (Packer, 2003, p. 25-26).

Berdasarkan beberapa pengertian di atas memberikan penjelasan bahwa kontekstual merupakan sebuah usaha untuk merelevankan teks pada konteksnya. Perjumpaan antara teks dan konteks akan melahirkan pemikiran yang kritis baik terhadap teks maupun konteks. Usaha ini akan mempelajari upaya rekonsiliasi antara teks dan konteks, dan antara konteks dengan konteks. Pemikiran rekonsiliasi ini akan mendorong seseorang melihat konteks secara benar dan bagaimana mengaplikasikan teks pada konteks secara tepat guna.

Dengan demikian dapat disimpulkan bahwa setiap penginjil hendaknya menyesuaikan Firman Allah yang tidak berubah itu dengan konteks masyarakat yang dihadapi. Dalam memberitakan Injil, Penginjil bukan membawa budayanya secara pribadi dan memaksakannya pada budaya orang lain, melainkan si Penginjil haruslah menyesuaikan Firman Tuhan dengan kebutuhan budaya setempat. Hal ini dilakukan agar komunitas yang ingin diinjili tidak melihat kekristenan sebagai suatu pemaksaan budaya asing ke dalam budaya mereka.

\section{Penginjilan Kontekstual Paulus}

Dalam bagian ini akan dibahas mengenai dasar dan sikap kontekstualisasi Paulus serta akan diuraikan tentang langkah-langkah kontekstualisasi yang digunakan Rasul Paulus dalam memberitakan Injil.

\section{Dasar dan Sikap Kontekstualisasi Paulus}

Paulus menempatkan Yesus sebagai pusat ajaran dan dasar dari penginjilannya. Inti berita yang disampaikan yaitu Yesus Kristus yang menyelamatkan manusia berdosa. Dasar tersebut yang Paulus kembangkan sebagai sikap terhadap kontekstualisasinya. Sehingga ia mampu menjangkau semua lapisan manusia dalam konteks. 


\section{Kontekstualisasi Kenotis}

Menurut Drewes Istilah "knotis" dalam bahasa Yunani eauton ekenosen (Heauton ekenosen) yang berarti "mengosongkan diri sendiri" (Drewes, 2006, p. 176). Dasar kontekstualisasi kenotis ini Paulus melihat sebagai sifat Kristus (Flp. 2:5-11). Sikap inilah yang Paulus terapkan dalam pelayanan kontekstualisasi. Sikap kenotis Kristus adalah dasar penting bagi terlaksananya proses kontekstualisasi. Paulus beranggapan bahwa untuk dapat mengontekstualisasikan Injil kepada semua lapisan manusia, penginjil harus menekankan sikap kenotis dalam dirinya. Dengan demikian Injil dapat diberitakan kepada semua manusia dalam konteks.

Sedangkan menurut Newbigin, Injil merupakan suatu berita yang bersifat murni dan tidak dipengaruhi oleh apapun (Newbigin, 2002, p. 203). Tetapi dalam pelaksanaannya, Injil selalu dipengaruhi oleh budaya penginjil (pembawa berita). Seperti halnya penginjilan Paulus di Atena, la tidak datang dengan Injil yang murni kemudiaan mengadaptasikan ke dalam kebudayaan orang Atena. Tetapi ia datang dengan Injil yang telah diwujudnyatakan dalam kebudayaan yang dengannya Paulus dibentuk. Namun bukan berarti kebudayaan Paulus harus menjadi kebudayaan orang Atena.

\section{Kontekstualisasi Pragmatis}

Kontekstualisasi yang Paulus maksudkan ialah sikap terhadap diri sendiri yang berguna atau berfaedah bagi pengembangan Injil dalam konteks. Paulus memberi penekanan mengenai kontekstualisasi pragmatis bahwa tugas pemberitaan Injil merupakan suatu keharusan. Sikap kontekstualisasi pragmatis ini Paulus kembangkan melalui dua cara.

Pertama, penginjilan sebagai tugas yang wajib. Penginjilan adalah suatu keharusan bagi Paulus bukan hanya suatu tugas yang netral sifatnya. Tidak ada pilihan lagi bagi Paulus untuk memberitakan Injil. kontekstualisasi pragmatis telah memberikan dasar yang penting baginya dalam memandang tugas pemberitaan Injil. Russell mengatakan, bahwa suatu bencana akan menimpa Paulus jika ia tidak memberitakan Injil (Russell, 2001, p. 47).

Berdasarkan uraian di atas dapat disimpulkan bahwa pemberitakan Injil merupakan prioritas utama bagi Paulus, karena Allah telah mempercayakan pelayanan pemberitaan Injil kepadanya. Sikap tersebut memampukan Paulus untuk mengembangkan dirinya dalam konteks yang kontekstual. Paulus memandang tugas penginjilan merupakan suatu tugas yang harus dilaksanakan.

Kedua, menjadi sama tapi tidak serupa. Paulus mengembangkan sikap kontekstualisasi pragmatis yang kedua dengan cara menjadi sama namun tidak serupa. Schreiter menjelaskan bahwa pada zaman Katolik Roma menyesuaikan refleksi Teologis dengan situasi setempat mulai mendapatkan dukungan yang murni, sehingga yang Paulus maksudkan "menjadi sama" ialah sikap untuk beradaptasi dengan semua konteks dan menjadikan dirinya orang dalam konteks tersebut. Sedangkan istilah "Namun tidak serupa" ialah Paulus tidak bertingkah laku seperti 
mereka (Schreiter, 2006, p. 6). Wesley dalam istilah ini memberikan pendapatnya bahwa "ia berdiri satu tingkat lebih tinggi dari pada mereka dan dengan kasihnya, Paulus hendak mengangkat mereka ke tempat yang lebih tinggi" (Wesley, 1998, p. 168). Tindakan untuk mengangkat mereka kepada tingkat yang lebih tinggi tersebut tidak kompromi dengan dosa maupun menentang kebenaran Alkitab. Dengan harapan Paulus dapat menarik orang-orang tersebut kepada Kristus.

Sedangkan Tomatala mengatakan bahwa, "semua orang yang tinggal di bumi ini memiliki kebutuhan dan pengharapan yang sama yaitu keselamatan. Keselamatan merupakan kebutuhan pokok dari semua orang yang masih bernafas" (Tomatala, 2001, p. 28). Berdasarkan penjelasan di atas maka dapat ditarik sebuah penegasan bahwa kemampuan Paulus dalam memandang pentingnya amanat penginjilan tidaklah terlepas dari dasar kontekstualisasi yang ia bangun. Dasar kontekstualisasi yang Paulus pergunakan selalu menggunakan dua unsur yaitu secara vertikal dan horizontal yaitu Paulus selalu mengutamakan Tuhan dalam sisi pemberitaan dengan memperhatikan latar belakang responden.

\section{Langkah-langkah Kontekstualisasi Paulus}

Halim mengatakan bahwa proses kontekstualisasi terlaksana dengan baik atau tidak ditentukan oleh tindakan dalam merealisasikannya. Sebaik apapun model yang dibuat, jika tidak direalisasikan maka proses kontekstual tersebut juga tidak akan pernah terwujud (Halim, 2003, p. 43). Berdasarkan teori tersebut dapat ditarik sebuah gagasan yaitu supaya dapat mencapai sebuah tujuan kontekstualisasi, maka seorang penginjil harus menetapkan sesuatu langkah atau prinsip sebagai perwujudan dari kontekstualisasi itu sendiri. Dalam hal ini Paulus menetapkan tiga langkah atau prinsip yaitu sebagai berikut.

\section{Memperhatikan Dimensi Pribadi}

Maitimoe menjelaskan bahwa memperhatikan dimensi pribadi ialah usaha untuk mengetahui keberadaan latar belakang responden secara pribadi maupun komunitas (Maitimoe, 2000, p. 35). Seperti pepatah mengatakan apa yang dihasilkan sekarang merupakan wujud dari cerminan masa lalunya. Kehidupan manusia pada umumnya dibentuk oleh dua unsur yaitu, unsur dalam (secara pribadi) maupun unsur luar (komunitas atau lingkungan). Keberadaan itulah yang membentuk seseorang menjadi suatu pribadi manusia secara utuh sebagai makhluk sosial dan budaya.

Paulus ketika mengadakan pendekatan penginjilan selalu berusaha untuk memperhatikan dimensi pribadi respondennya. Karena Paulus sendiri menyadari bila setiap orang memiliki latar belakang yang berbeda antara yang satu dengan yang lainnya. Ada orang yang berlatang belakang Yahudi, tetapi ada juga yang berlatar belakang Yunani. Ada pula orang yang mempunyai latar belakang pendidikan tinggi dan terhormat, namun ada yang tidak mendapat kesempatan untuk sekolah dan lemah keadaannya (Budiman, 2007, p. 34). Keadaan tersebut juga akan menentukan reaksi mereka dalam mendengarkan Injil yang diterimanya. Berdasarkan beberapa 
penjelasan di atas dapat disimpulkan bahwa memperhatikan dimensi pribadi responden merupakan langkah yang tepat untuk mewujudkan kontekstualisai.

\section{Menjawab Kebutuhan Manusia dalam Konteks}

Tomatala menyebutkan bahwa Paulus selalu menempatkan Firman secara tepat, sesuai dengan kebutuhan setiap orang di dalam konteks. Penempatan Firman yang menjawab kebutuhan dalam konteks bagi Paulus bersifat situasional. Sebab Firman yang absolut tersebut berbicara secara selektif dalam menjawab kebutuhan semua orang dalam konteks (Tomatala, 2002, p. 70). Firman yang dimaksudkan di sini adalah Yesus Kristus. Yesus Kristus yang adalah Injil itu sendiri merupakan inti dari pemberitaan Paulus.

Berdasarkan pandangan di atas maka dapat tarik sebuah kesimpulan bahwa prinsip bahwa Firman menjawab setiap kebutuhan manusia dalam konteks merupakan langkah yang tepat dalam mewujudkan Injil yang universal. Sehingga kebudayaan tidak menjadi penghalang terealisasinya penginjilan, tetapi justru kebudayaan menjadi wujud nyata dari Injil yang bersifat universal. Paulus berusaha menyajikan berita Injil melalui bentuk-bentuk budaya orang Atena, supaya Injil dapat menjawab kebutuhan mereka tentang keselamatan. Dalam bagian selanjutnya akan dibahas dan dipaparkan tentang prinsip kontekstual yang Paulus gunakan untuk memberitakan Injil di Atena.

\section{Mempergunakan Simbol dalam Konteks}

Kata "simbol" dalam Kamus Besar Bahasa Indonesia berarti "suatu harapanharapan atau lambang-lambang" (KBBI, p. 1066). Semua kebudayaan pada umumnya mempunyai suatu simbol-simbol tertentu sebagai pencirian dari kebudayaan tersebut. Dalam bidang keagamaan pun berlaku hal yang sama, bahwa agama juga memiliki simbol atau harapan-harapan tertentu, sebagai identitas atau harapan dari keyakinan mereka. Mahatma Gandhi pernah berkata, "idolatry is bad, not so idol worship," yang penulis artikan "penyembahan berhala itu buruk, tetapi tidak demikian dengan citra yang dianggap merepresentasikan Tuhan." Maksudnya Gandhi ingin menunjukan bahwa sebenarnya setiap agama tidak bisa melepaskan diri dari simbolsimbol untuk mempermudah dalam memahami Tuhan itu sendiri (Ngakan, 1997, p. 104).

Paulus menerapkan prinsip yang sama dalam penginjilan lintas budaya yaitu Paulus menggunakan simbol-simbol (harapan atau lambang) yang dikenal oleh responden untuk menjelaskan Injil. Paulus menuntun jalan pimikiran responden melalui harapan-harapan yang mereka kenal tentang Allah. Harapan-harapan tersebut sebagai modal untuk menjelaskan eksistensi tentang Allah melalui Injil. Supaya responden merasa lebih dekat terhadap jalan pemikiran Injil dan berita Injil menjadi relevan dalam kehidupannya. Paulus dalam konteks ini bermaksud supaya gambaran-gambaran yang sudah mereka mengerti akan menolong orang Atena dalam menerima berita Injil. 


\section{METODE}

Dalam artikel ini penulis menggunakan metode penelitian kualitatif dengan sebuah pendekatan ilmu hermeneutik. Menurut sugiyono metode penelitian kualitatif adalah metode penelitian yang digunakan untuk meneliti pada kondisi objek yang alamiah di mana peneliti sebagai instrumen kunci (Sugiyono, 2016, p. 9). Objek penelitian ini adalah perspektif Alkitab tentang ajaran Paulus mengenai konsep Pendekatan Penginjilan Kontekstual Paulus Berdasarkan Kisah Para Rasul 17:16-34. Bentuk pendekatan yang digunakan adalah pendekatan eksegesis di mana teknik pengumpulan data adalah melakukan penafsiran terhadap teks dengan bantuan kajian ilmu hermeneutik dan dibantu buku-buku dan literatur yang berhubungan dengan konteks Penginjilan Kontekstual Paulus dalam Kisah Para Rasul 17:16-34. Dalam penelitian kualitatif, terdapat metode pengumpulan data dengan studi hermeneutik untuk penelitian Alkitabiah. Mulyono berpendapat bahwa Hermeneutik adalah salah satu jenis filsafat yang mempelajari tentang interpretasi makna (Mulyono, 2012, p. 20). Teknik analisis data yang akan dilakukan adalah mereduksi semua data dalam bentuk penafsiran teks dalam konteks Kisah Para Rasul 17:16-34 kemudian membuat integrasi tentang pendekatan penginjilan Paulus di Atena.

\section{HASIL DAN PEMBAHASAN}

\section{Analisis Konteks Kisah Para Rasul 17:16-34}

Kunjungan Paulus ke Atena berbeda dengan kunjungan di kota-kota lain. Di kota Atena Paulus bertemu dengan golongan kaum intelektual. Mereka ialah orangorang yang berilmu tinggi, suka berdiskusi dan mendengarkan hal-hal yang baru. Diskusi-diskusi yang mereka gemari tersebut Paulus gunakan sebagai bentuk pendekatan kepada masyarakat Atena dalam rangka memberitakan Injil. Paulus bermaksud melalui pendekatan tersebut dapat menjadi sebuah jembatan kepada berita Injil yang hendak disampaikan. Karena Paulus menyadari bahwa kehidupan dan cara pandang orang Atena terhadap segala sesuatu berbeda, maka Paulus menggunakan cara-cara pendekatan yang dapat dikenali oleh orang-orang Atena.

\section{Keadaan Kota Atena}

Atena ialah Kota yang terletak di tanah Yunani. Dahulu Atena terkenal sebagai pusat kebudayaan Timur Tengah dan pusat intelek dunia. Di Atena terdapat sebuah universitas terbesar di seluruh dunia kuno. Banyak orang-orang dari seluruh dunia datang untuk menuntut ilmu di Kota Atena. Di samping itu, hasil kerajinan dan keadaan politik juga berpengaruh bagi dunia. Dengan keadaan yang demikian, Atena pernah mencapai masa kejayaan. Tetapi pada abad selanjutnya mengalami kejatuhan, karena Kota tersebut direbut oleh bangsa Romawi pada tahun 86 SM. Dipihak lain, Kota Atena juga terkenal dalam penyembahan kepada berhala. Dilihat dari sejarah Kota Atena begitu menarik, karena penyembahan berhala tidak dapat dipisahkan 
dengan filsafat (Brink, 2003, p. 278). Atena adalah kota terbesar di tanah Yunani. Pada tahun kurang lebih 249 SM, kota Atena mengalami puncak kejayaan di bawah pimpinan Perikles sesudah pertempuran dengan Persia pada pertengahan abad kelima berakhir. Kehidupan di bidang politik, perdagangan dan kebudayaan berkembang dengan pesat (Dixon, 1997, p. 125).

\section{Keadaan Relegius di Atena}

Atena bukan hanya kota yang dipenuhi dengan para ahli filsafat, tetapi juga penuh dengan patung berhala dan dewa-dewa. Menurut pengamatan Paulus, kota Atena dipenuhi dengan patung berhala (Kis. 17:16). Baik di tempat-tempat umum maupun di rumah-rumah pribadi terdapat begitu banyak patung berhala dan dewadewa. Menurut Charles, di Atena orang lebih banyak menemukan suatu ilah (dewa) daripada seorang manusia, dan mengabarkan bahwa di Atena terdapat patungpatung berhala yang melebihi jumlah di seluruh tanah Yunani (Charles, 2001, p. 463).

Penyembahan berhala tersebut memiliki pengaruh terhadap asusila orang Atena, karena dewa mengijinkan dan mendukung setiap nafsu. Seperti yang dilakukan dan diajarkan oleh para pengikut Atraditus, bahwa berbuat zinah dalam kuil berhala sebagai satu cara dalam upacara agama. Para pengikut Bachus mencurahkan minuman keras sebagai korban curahan kepada dewa mereka dalam pesta minum-minum sampai mabuk (Emil, 1982, p. 85). Penyembahan-penyembahan yang mereka lakukan berdampak pada kebobrokan moral, karena perbuatan zinah, percabulan dan penyimpangan lainnya tidak dipandang sebagai suatu kejahatan.

\section{Pendekatan Penginjilan Kontekstual Paulus Berdasarkan Kisah Para Rasul 17:16-34}

Paulus menyadari bahwa pandangan orang-orang Atena terhadap segala sesuatu berbeda. Sehingga untuk dapat memberitakan Injil kepada orang Atena Paulus memerlukan pendekatan yang kontekstual supaya dapat dipahami dan dimengerti oleh orang Atena. Kontekstualisasi terjadi ketika penginjilan disampaikan kepada konteks budaya dan cara pandang yang berbeda, namun berita Injil tetap relevan bagi mereka. Paulus menggunakan budaya orang Atena dalam mewujudkan kontekstualisasi dan didasarkan pada kebenaran Alkitab baik secara langsung maupun tidak langsung. Paulus mengharapkan agar orang-orang Atena menyadari, bahwa penyembahan kepada patung berhala merupakan suatu tindakan kebodohan belaka.

\section{Pendekatan Penginjilan Kontekstual Paulus}

Penulis dalam bagian ini menjelaskan tentang model-model pendekatan penginjilan kontekstual Paulus di Kota Atena. Dalam melaksanaan penginjilan ada beberapa model pendekatan kontekstualisasi penginjilan Paulus kepada orang-orang Atena dilihat dari Kisah Para Rasul 17:16-34 sebagai berikut. 
Model Dialog Interaktif Persuasif (ay. 17-18)

Teks yang terdapat dalam ayat 17-18 ini memperlihatkan keprihatinan serta kesedihan Rasul Paulus terhadap orang yang tertarik kepada ajaran Yudaisme, golongan Epikuros, Si Peleter, Stoa, Pemberita ajaran dewa-dewa dan orang-orang yang menyembah berhala. Yune Sun Park menjelaskan bahwa Paulus memberitakan Injil dengan berbagai kedudukan sosial, sikap Paulus dilakukan sesuai dengan prinsipnya (Yune Sun Park, 2001, p. 260). Dengan demikian dapat dijelaskan bahwa Paulus berbicara kepada berbagai kelompok tersebut dengan cara yang berbeda: kepada orang Yudaisme Paulus menggunakan Perjanjian Lama, tetapi orang-orang yang tidak mengenal Allah Paulus berusaha mencari beberapa kesamaan dasar.

Dalam ayat ini terlihat jelas bahwa Paulus menggunakan pendekatan bertukar pikiran. Paulus membawa orang Yahudi pergi ke pasar untuk bertukar pikiran dan memberitakan Injil kepada orang-orang kafir di Atena. Dixon mengemukakan bahwa yang dimaksud istilah pasar dalam konteks ini bukan berarti pasar ikan atau pasar dagang biasa melainkan satu bagian kota yang dikhusukan untuk orang beramairamai mengadakan dialog (Dixon, 1997, p. 126). Istilah tukar pikiran dan bersoal

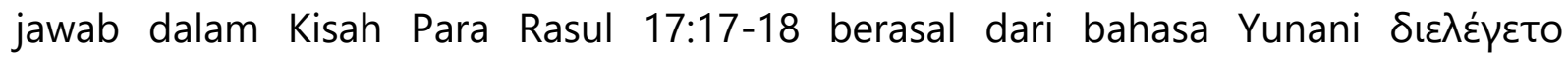
(dielegote) dari kata dasar $\delta \iota \alpha \lambda \varepsilon ́ \gamma o \mu \alpha \iota$ (dialegomai) merupakan bentuk kata kerja imperfekt indikatif aktif orang ketiga tunggal. Imperfekt indikatif aktif berkenaan dengan tindakan masa lampau yang dipakai secara duratif (menyatakan suatu perbuatan yang terus-menerus) dan iteratif (menyatakan suatu perbuatan yang terjadi berulang-ulang; Ray Summer, 2007, p. 15). Kata ini dapat diartikan sebagai suatu diskusi yang memberi alasan, bercakap-cakap dengan arus bolak-balik kepada lawan, berbicara dalam rangka meyakinkan alamat tentang pengetahuan sesuatu kepadanya.

Cara-cara $\delta ı \lambda \varepsilon \dot{\gamma \varepsilon \tau o ~(d i e l e g e t o) ~ P a u l u s ~ t e r s e b u t, ~ p e n u l i s ~ m e n g i s t i l a h k a n ~ d e n g a n ~}$ model dialog interaktif persuasif. Dialog interaktif persuasif yaitu percakapan yang melibatkan orang dalam konteksnya dan bertujuan untuk meyakinkan orang tersebut, bukan dengan kekerasan dan konflik tetapi secara persuasif (Schreiter, 1993, p. 26).

Berdasarkan analisis dan penjelasan di atas maka dapat disimpulkan bahwa pendekatan dialog interaktif tersebut menolong Paulus dalam berkomunikasi dengan orang Atena. Di mana Paulus mengambil inisiatif untuk berdialog tentang agama, baik dengan sesama orang beriman, orang-orang pasar-umum, ahli pikir cendikiawan intelektual. Karena perlu disadari bahwa cara pandang terhadap segala sesuatu bisa jadi berbeda dengan cara pandang Injil. Melalui dialog tersebut, Paulus dapat menjalin sebuah hubungan dengan orang Atena dalam rangka meyakinkan mereka terhadap berita Injil yang disampaikan. Sehingga Paulus dapat menemukan apa yang telah mereka mengerti dan apa yang yang belum dimengerti mengenai berita Injil yang mereka dengar. 
Model Identifikasi Religio-Kultural (ay. 22-23)

Usaha-usaha Paulus untuk mengenal keadaan masyarakat Atena tersebut dengan menggunakan model identifikasi religio-kultural. Istilah "Identifikasi" mempunyai arti "menentukan atau menetapkan ciri-ciri atau keadaan khusus seseorang, benda dan keadaan lainnya". Sedangkan identifikasi religio-kultural yaitu sikap dalam menentukan atau menetapkan keadaan khusus dari kebudayaan maupun keagamaan di tempat Injil diberitakan. (KBBI, p. 417). Willowbank berpendapat bahwa "mengidentifikasi keadaan masyarakat yang diinjili, maka paling tidak penginjil mengetahui bahasa, budaya, maupun keagamaan yang terdapat di dalamnya." Konteks ini menjelaskan bahwa Paulus ingin mengenal apa yang sebenarnya diyakini oleh masyarakat di Atena, baik secara budaya, tradisi, pemujaan serta ibadah (Willowbank, 2007). Sedangkan Brink mengatakan bahwa ketika berdiri di tengahtengah dewan itu, Paulus berusaha mencari titik temu dengan mengatakan bahwa mereka 'sangat beribadah' terjemahan ini lebih tepat ketimbang sangat percaya takhayul, namun kedua pengertian ini bisa dipakai (Brink, 2001, p. 289). Paulus juga menyinggung hal kedua yang dilihatnya, yaitu suatu mezbah dengan tulisan "Agnostos Theos", kepada allah (theos) yang tidak dikenal. Pausanias dan Philostratos mengatakan bahwa memang di Atena ada mezbah-mezbah yang diperuntukkan bagi "allah yang tidak dikenal" (Dixon, 1997, p. 126). Paulus memakai hal tersebut, bahwa ia akan memperkenalkan "THEOS yang belum pernah dikenal mereka" dan Paulus memperkenalkan Allah yang hidup, Allah yang ia sembah.

Berdasarkan beberapa pandangan di atas maka dapat ditarik sebuah pengertian bahwa penjelasan Paulus merupakan suatu jembatan untuk memberitakan sifat Allah Sang Khalik (ay. 24-25), bahwa manusialah yang hidup dari kasih karunia/belas kasihan Allah. Allah tidak membutuhkan atau tidak hidup dari pemberiaan manusia, tetapi manusia harus berbakti kepada Allah. Dalam konteks inilah Paulus mengadakan pendekatan terhadap pengertian 'agama buatan manusia' yang dalam intisarinya justru menyimpang dari ibadah yang sejati kepada Allah. Paulus dalam konteks ini sedekat mungkin ingin mendekati cara berpikir pendengarnya, tetapi ia juga memberikan penjabaran baru mengenai pribadi Allah yang hidup. Paulus berusaha melukiskan kenyataan dengan suatu kata yang sudah dikenal oleh masyarakat Kota Atena dalam syair-syair Yunani. Maksud dari tujuan Paulus ialah memberikan pengertian serta dengan tegas menyatakan bahwa perkembangan naluri keagamaan orang Atena itu sebagai tindakan dosa. Selanjutnya dalam konteks ini Paulus mulai menjelaskan dengan sangat teliti tentang Allah yang tidak dikenal oleh orang Atena dengan mencari titik kontak untuk berkomunikasi dengan mereka.

Model Akomodasi Lokatif (ay. 19,22)

Menurut KBBI kata "Akomodasi" berarti sesuatu yang disediakan untuk memenuhi kebutuhan, sedangkan istilah kata "Lokatif" mempunyai arti kasus yang menunjukan makna tempat pada nomina atau sejenisnya (KBBI, 681). Rasul Paulus memberikan istilah model akomodasi lokatif terhadap pemanfaatan tempat yang 
bermakna khusus bagi kehidupan orang Atena. Maksud Paulus tentang Akomodasi Lokatif adalah suatu tempat yang bermakna khusus di dalam kalangan atau orang yang diinjili dan dipakai sebagai sarana untuk menjelaskan Injil guna memenuhi kebutuhan mereka tentang keselamatan. Hanry berpendapat tempat yang dimaksud dalam ayat ini ialah Aeropagus. Dalam bahasa Yunani "Apeıc (areios pagos), merupakan bentuk kata benda akusatif maskulin tunggal, artinya: Bukit Ares; Bukit Mars (Hanry, 1996).

Sedangkan Park dalam bukunya yang berjudul Tafsiran Alkitab Kisah Para Rasul mengatakan bahwa: 'Areopagus' adalah bukit di sebelah barat laut Akropolis Atena yang menjulang tinggi, di puncak bukit ini pernah berdiri beberapa mezbah, kuil suci, dan patung Yunani, serta mahkamah agung Areopagus di tempat terbuka. Areopagus ini adalah tempat di mana orang Atena berkumpul dan bersidang, serta berdiskusi mengenai segala sesuatu yang berhubungan dengan agama dan filsafat (Park, 2001, p. 262). Paulus dibawa ke 'Areopagus' (Bukit Dewa Mars) bukan untuk diadili tetapi untuk diberi kesempatan agar ia berceramah tentang kebenaran dengan bebas. Penghuni Kota Atena ingin mendengarkan ajaran yang baru karena keinginan belajar.

Berdasarkan uraian di atas maka dapat disimpulkan bahwa mempergunakan momen-momen penting yang terdapat di dalam responden merupakan suatu proses kontekstualisasi yang tepat. Karena momen-momen tersebut mempunyai makna yang lebih bagi kehidupan mereka. Ketika momen-momen tersebut dimanfaatkan untuk penjelasan Injil maka dengan sendirinya responden akan lebih menaruh perhatian terhadap berita Injil yang didengar.

Model Adopsi Literalis (ay. 23-24)

Kata "adopsi" berarti mengangkat atau mengambil, dan "literalis" dari kata literal berarti "menerjemahkan secara harfiah" (KBBI, 388). Sedangkan maksud Rasul Paulus mengenai adopsi literalis ialah usaha untuk mengambil atau mengangkat beberapa kata atau kalimat yang mengandung nilai-nilai kebudayaan responden dan memiliki implikasi yang sepaham dengan iman Kristen (dengan kata lain titik temu). Misalnya, kata keselamatan, semua orang mempunyai pengharapan yang sama tentang keselamatan walaupun konsep dari keselamatan tersebut berbeda.

Pengertian orang Atena tentang Allah dan keberadaan manusia merupakan titik temu yang memiliki implikasi dengan kebenaran Injil. Melalui pemahaman mereka, Paulus menjelaskan eksistensi Allah yang benar yaitu bahwa Allah yang benar yaitu bahwa Allah sang pencipta adalah Allah yang sempurna dan berkuasa (ay. 24-25). Donald mengatakan: Allah tidak membiarkan dosa mengusai manusia terus-menerus. Tetapi Allah menjanjikan keselamatan dalam pribadi Yesus yang mati di atas kayu salib dan dibangkitkan (ay. 30). Supaya manusia yang percaya Yesus dapat kembali kepada Allah yang llahi (sempurna dan suci). Karena keadaan Ilahi tidak dapat disamakan dengan emas, perak ataupun batu ciptaan kesenian dan keahlian orangorang Atena. Seperti yang digambarkan mereka dalam wujud patung-patung berhala yang indah ciptaan mereka ayat 29 (Donald, 2000, p. 1808). 
Melalui penjelasan tersebut dapat ditarik sebuah kesimpulan bahwa tujuan utama dari proses kontekstualisasi ialah mempermudah pendengar menerima berita Injil. Mengadopsi nilai-nilai budaya responden merupakan salah satu langkah dalam menolong jalan pikiran mereka terhadap Injil yang didengarnya.

\section{KESIMPULAN}

Pada bagian terakhir ini penulis akan memaparkan kesimpulan dari uraian analisis sebelumnya. Kesimpulan yang didapatkan pembahasan yang dilakukan mengenai Pendekatan penginjilan kontekstual Paulus berdasarkan Kisah Para Rasul 17:16-34. Penguraian kesimpulan berhubungan dengan pembahasan melalui metode yang dipakai dalam menulis jurnal ilmiah ini. Istilah kontekstual selalu dipakai dalam dunia teologi penginjilan dan misi. Istilah ini menunjuk kepada suatu pola pendekatan penginjilan atau misi yang bisa diterima oleh konteks di mana aksi penginjilan atau misi dilakukan. Kewajiban mengabarkan Injil adalah tanggung jawab setiap orang yang telah menerima Kristus menjadi Tuhan dan Juruselamatnya. Orang Kristen perlu melakukan penginjilan supaya Injil dapat didengar dan diterima oleh semua orang dalam konteks budaya. Dari kondisi dan latar belakang seperti itulah maka kontekstualisasi merupakan langkah atau upaya yang tepat untuk membahasakan berita Injil ke dalam masyarakat yang majemuk sekarang ini. Setiap penginjil harus benar-benar dipersiapkan dan dibekali dengan pemahamanpemahaman yang tepat dan benar mengenai Injil agar berita yang disampaikannya pun adalah berita yang benar dan tepat tentang Kristus.

Berdasarkan hasil analisis terhadap Pendekatan penginjilan kontekstual Paulus berdasarkan Kisah Para Rasul 17:16:34, maka dapat ditarik sebuah kesimpulan sebagai contoh model penginjilan kontekstual masa kini. Dasar dan sikap kontekstualisasi Paulus yaitu kontekstualisasi kenotis dan kontekstualisasi pragmatis di mana dalam hal ini menguraikan tentang dua hal yakni: penginjilan sebagai tugas yang wajib dan menjadi sama tapi tidak serupa. Sedangkan langkah-langkah kontekstualisasi Paulus yakni dengan memperhatikan beberapa hal di antaranya adalah: memperhatikan dimensi pribadi, menjawab kebutuhan manusia dalam konteks dan mempergunakan simbol dalam konteks. Kemudian hasil dari analisis tentang pendekatan penginjilan kontekstual Paulus menghasilkan beberapa prinsip yakni: model dialog interaktif persuasif (ay. 17-18), model identifikasi religio-kultural (ay. 22-23), model akomodasi lokatif (ay. 19, 22), model adopsi literalis (ay. 23-24).

\section{KEPUSTAKAAN}

(2008). Kamus Besar Bahasa Indonesia. Jakarta: Gramedia Pustaka Utama.

Balleit, Emil. (1982). Kisah Para Rasul. Malang: Gandum Mas.

Bosch, David J. (2001). Transformasi Misi Kristen. Jakarta: Gunung Mulia.

Brill, J. Wesley. (1998). Tafsiaran Surat Korintus Pertama. Bandung: Kalam Hidup. 
Budiman, L. (n.d.). Pelayanan Lintas Budaya dan Kontekstualisasi. n.p.: n.p.

Dixon, R. (1997). Tafsiran Kisah Para Rasul. Malang: Gandum Mas.

Drewes, B. F., Wilfrid Haubeck dan Hanrick Von Siebenthal. (2006). Kunci Bahasa Yunani Perjanjian Baru. Jakarta: Gunung Mulia.

Dwiraharjo, S. (2019). Kajian Eksegetikal Amanat Agung menurut Matius 28:18-20. JURNAL TEOLOGI GRACIA DEO, 1(2), 56-73. https://doi.org/10.46929/graciadeo.v1i2.8.

Ellis D. W. (1999). Teologi Penginjilan. Jakarta: Yayasan Bina Kasih/OMF.

Halim, Makmur. (2003). Model-Model Penginjilan Yesus. Malang: Gandum Mas.

Hanry, Matthew. (1996). Commentary, "Act 17:17-18", CD-ROOM, Bible Work For Window.

Hasselgrave David J., dan Edward Rommen. (2004). Kontekstualisasi. Jakarta: Gunung Mulia.

(1997). Planting Churches Cross-Culture Aguide for Home and Foreign Missions. United States: Baker Book House. (2001). Communicating Christ Cross Culturally. Malang: SAAT Malang.

Jenson, Ron dan Jim Stevens. (2002). Dinamika Pertumbuhan Gereja. Malang: Gandum Mas.

Lausanne Committee For World Evangelization. (1978). The Willowbank Report:

Consultation on Gospel and Culture (LOP 2).

https://www.lausanne.org/content/lop/lop-2.

Madrasuta, Ngakan Made. (1997). Hindu di antara Agama-agama. Denpasar: Upada Sastra dan Yayasan Dipa.

Maitimoe. (2000). Membina Jemaat Misioner. Jakarta: Gunung Mulia.

Manurung, K. (2020). Efektivitas Misi Penginjilan dalam Meningkatkan Pertumbuhan

Gereja. DUNAMIS: Jurnal Teologi dan Pendidikan Kristiani, 4(2), 225-233.

https://doi.org/10.30648/dun.v4i2.242.

Matakupan, Thomy J. (2002). Prinsip-prinsip Penginjilan. Surabaya: Momentum.

Mulyono, Edi. (2012). Belajar Hermeneutik. Yogyakarta: IRCisod.

Newbigin, Lesslie. (2002). Injil dalam Masyarakat Majemuk. Jakarta: Gunung Mulia.

Packer, J. I. (2003). Evangelism And The Sovereignty Of God. Surabaya: Momentum.

Panggarra, R., \& L. Sumule. (2019). Pengaruh Pelayanan Pemuda Berbasis Kontekstual

Terhadap Pertumbuhan Gereja Kemah Injil Indonesia di Kota Samarinda. Jurnal

Jaffray, 17(1), 91-106. doi: http://dx.doi.org/10.25278/jj71.v17i1.325.

Park, Yune Sun. (2001). Tafsiran Alkitab Kisah Para Rasul. Malang: YPPII.

Pfeiffer, Charles F., dan Everett F. Harrison. (2001). The Wycliffe Bible Commentary. Malang: Gandum Mas.

Schreiter, Robert J. (1993). Rancang Bangun Teologi Lokal. Jakarta: Gunung Mulia.

Spitter, Russell P. (2001). Pertama dan Kedua Korintus. Malang: Gandum Mas.

Stamps, Donald C. (2000). Alkitab Penuntun Hidup Berkelimpahan. Malang: Gandum Mas. 
Stephanus, D. S. P. (2019). Mengajarkan Penginjilan sebagai Gaya Hidup Orang

Percaya. REDOMINATE: Jurnal Teologi Dan Pendidikan Kristiani, 1(1), 12-22.

https://sttkerussoindonesia.ac.id/e-journal/index.php/redominate/article/view/2.

Sugiyono. (2016). Metodologi Penelitian Kuantitatif, Kualitatif, dan R\&D. Bandung: CV Alfabeta.

Summer, Ray. (2007). Bahasa Yunani Perjanjian Baru. Yogyakarta: STTII.

Tenibemas, P. (2019). Andil Kita Dalam Misi Masa Kini. Pengarah: Jurnal Teologi

Kristen, 1(1), 23-36. https://doi.org/https://doi.org/10.36270/pengarah.v1i1.4.

Tomatala, Yakub. (2001). Teologi Kontekstualisasi. Malang: Gandum Mas. . (1988). Penginjilan Masa Kini, Jilid I Malang: Gandum Mas. . (2002). Penginjilan Masa Kini Jilid I. Malang: Gandum Mas.

van den Brink, H. (2001). Tafsiran Alkitab Kisah Para Rasul. Jakarta: Gunung Mulia. . (2003). Tafsiran Alkitab Kisah Para Rasul. Jakarta: Gunung Mulia. 